\title{
Concept of Hair Problems and its Treatment in Ayurveda
}

Sharma Neeru ${ }^{1}$, Yadav Yadevendra ${ }^{2^{*}}$, Sharma Usha ${ }^{3}$, Sharma Khem Chand ${ }^{4}$

${ }^{1}$ P. G. Scholar, P. G. Department of Rasa Shastra evum Bhaishajya Kalpana, Uttarakhand Ayurved University, Rishikul Campus, Haridwar

${ }^{2}$ Assistant Professor, P. G. Department of Rasa Shastra evum Bhaishajya Kalpana, Uttarakhand Ayurved University, Rishikul Campus, Haridwar

${ }^{3}$ Associate Professor, P. G. Department of Rasa Shastra evum Bhaishajya Kalpana, Uttarakhand Ayurved University, Rishikul Campus, Haridwar

${ }^{4}$ Professor and H. O. D, P. G. Department of Rasa Shastra evum Bhaishajya Kalpana, Uttarakhand Ayurved University, Rishikul Campus, Haridwar

DOI: $10.36348 /$ sijtcm.2020.v03i02.004

| Received: 01.02.2020 | Accepted: 08.02.2020 | Published: 26.02.2020

*Corresponding author: Yadevendra Yadav

\section{Abstract}

Hair plays a vital role in enhancing the personality of a human. As the hair is the first noticeable part of beauty for women as well as men. The scalp and hair conditions also have more psychological impact on human societies. Even minor changes in hairs like greying of hair, early hair fall affect the self-confidence and self-esteem of an individual. Acharya Charka considered Hair as Mala (Waste product) of Asthi Dhatu (Bone), while Sharngdhara thinks it as a Updhathu (tissue) of Asthi. Various Ayurvedic Jagran is described in different Classics for the disease of Hairs like Khalitya (Hair loss), Palitya (Premature Greying of Hairs) Indralupta (Alopecia areata) and Darunaka (Dandruff) etc. Like other disorders of body disbalance of Vatta, Pitta and Kapha are also involves in the aetiopathogenesis. Keshya (Hair tonic) Keshya-Samjanana (Hair revitalizer) and Keshya-Ranjana (Natural hair restoring agent) are used to treat hair fall and pre-mature greying of hair. The greying of hair and wrinkle on the face are the two important cardinal features of aging. Classical Ayurvedic Chikitsasutra (treatment guideline) advocated the Poshana (nourishment) of Dhatu for the normal growth of Updhatu and Mala. Similarly, the treatment of Mula (Origin) of Srotas (micro and marco channels of body) is also considered in the treatment. Indian Gooseberry, false Daisy, true indigo, iron-containing compounds and other herbs are used as Rasayana (rejuvenator), Panchkarama, Snehana and Vasti Chikitsa to treat hair disorders.

Keywords: Hair Problems, Ayurvedic, Rasayana.

Copyright @ 2020: This is an open-access article distributed under the terms of the Creative Commons Attribution license which permits unrestricted use, distribution, and reproduction in any medium for non-commercial use (NonCommercial, or CC-BY-NC) provided the original author and source are credited.

\section{INTRODUCTION}

Ayurveda is more than a healing system [1]. It is an ultimate science and art for an appropriate lifestyle, which helps us to achieve longevity. Improper Aahara (diet) [2, 3], not following the principle of Dincharya (Daily routine) [4] and Ritucharya [5] living in polluted environment and stressful work culture fasten the process of ageing. Rasayana [6] is the group of medicine and activities which decrease \& revert the process of ageing. Besides Rasayana dravaya, Rasa (Mercury) [7] Lauha (Metals) [8] Ratana (Gems)[9] Visha (Poisons)[10] and some formulations are works as Rasayana. Vali (Wrinkles), Palita, Kalitya, Age spot, sagging skin, dull skin tone and thin skin are chief cardinal feature of aging. Beautiful, long and attractive hairs of the scalp enhancing factor to the personality.

Among these Aakal-Palitya, Khalitya and
Darunaka are chief common hair problems.
Disturbance of Trisdosa are the main reason of these
disease and disorder. In modern medical science many
factors contribute to hair diseases i.e family history (heredity), harmonal changes due to pregnancy, childbirth, menopause and thyroid problems. So hair problems are the manifestation of many diseases. Medical conditions i.e scalp infections such as ringworm and hair pulling disorder called trichotillomania. May be due to side effects of certain drugs, such as those used for cancer, arthritis, depression, heart problems, gout and high blood pressure. General thinning of hair after a physical or emotional shock. Excessive hairstyling or hairstyles that pull your hair tight, such as pigtails, can cause a type of hair loss called traction alopecia [11]. The main reason behind the upsurge of hair problems are more frequently seen due to extremely busy schedule of working hours, pollution of the environment and unhealthy dietary habits [12]. There are many types of treatments, medicines, supplements and Shampoos are available in the markets. Most of the formulation is over-the-counter products. So, without taking the advice of the expert, result of these is not getting proper. Most of the market products claim that they are safe because of herbal or Ayurvedic preparation. Here 
we are discussing and exploring some common hair problems and explaining the ayurvedic terminology for medicine used, and drugs.

\section{Kesh (scale hair)}

A normal human being has approximately 1 million hair follicles on his body, of which 1 lack hairs on the scalp. A hair normally grows at the rate of approximately $1 \mathrm{~cm}$ per month, but each hair grows in cycles, each cycle being constituted by -

- The growth phase (Anagen)

- The transition phase (Catagen)

- $\quad$ The resting phase (Telogen)

The catagen phase in a hair cycle usually lasts 3 weeks, while the telogen phase lasts 3 months. The duration of the anagen phase in different hair follicles however, varies depending upon the site of the body. In the scalp hair the duration of anagen phase can be as long as 10 years. After completing the anagen phase, each hair follicle enters into the catagen phase which is followed by telogen phase. The old hair however, falls off only after the completion of the telogen phase and when the new hair has already started growing in its place [13]. In Ayurveda hairs are known as Kesha. The word 'Kesha' originally has been brought about from "shee" with "ach + aluk samasah" which has been explained as "ke mastake shete iti" by HalayudhaKosha [14].

\section{Postana (Nutrition) of Kesha}

In the origin and development of Kesha i.e. hair, there is significant need of Prithvi (earth element) and Akasha (space/ether) Mahabhoota. According to Acharya Charaka ingested food is digested to assimilable nutritional fluid (Ahara rasa) which further divides into two parts namely - Sara Bhaga (essential fluid) and the Kitta (excretory matter/waste matter). The waste matter is responsible for the production and nutrition of so many things like sweat, urine, hair, etc., and among them are the hair follicles the hair of the head and beard, hair of the body, etc., [15] According to Sushruta Kesha nutrition form the end part of Dhaman (Circulation), which are attached to the Romakoops[16].In Ayurveda there are seven Dhatu (tissue) in the body. Jataragni (Digestive power) is the main Agni that convert Ahar into Ahar Rasa (essence of food), which further converted into Seven Dhatu by the Dhatuagni and Bhutagni. The concept of process of transformation of one Dhatu into subsequent Dhatu is called Dhatu Poshana Naya in Ayurvedic doctrine. This type of conversion comes under Kshir Dadhi Nyaya \& Kedari kuliya Nyaya. But Acharya Chakrapani strongly discarded the Kala-Kapota Naya. So if one Dhatu is assessing as under nutrition than nutrition of former Dhatu is necessary [17]. During the process of formation and development of hair, the successive role of other tissues can also be estimated; because, though its origin begins at the earliest for its appearance it takes much time. So the role of subsequent Dhatus (Tissue) like Asthi (Bone) and Majja (Bone marrow) can be well judged because hair is a Mala (By product) of Asthi Dhattu (Bony tissue) and Majja is subsequent tissue.

The word 'Keshya' is suggestive of 'Keshaaya Hitam Yat Tat'. It means that which is good for hair. Various Keshya drugs described in Bhav Prakash Nighantu are mentioned in table No.1.

Table No. 1

\begin{tabular}{|c|l|l|l|l|}
\hline S. No & Sanskrit Name & English Name & Botanical Name & Part Used \\
\hline 01 & Vibhitaki & Bastard myrobalan & Myrobalanus bellirica Gaertn & flower \\
\hline 02 & Yastimadhu & Liquorice & Glycyrrhiza glabra & Root \\
\hline 03 & Bakuchi & Bavacalu & Psoralea corylifolia & fruit \\
\hline 04 & Bhallataka & Marking nut & Semecarpus anacardium Linn & Stalk \\
\hline 05 & Gambhari & White teak & Gmelina arborea & flower \\
\hline 06 & Sindhuvara & Five-leaved chaste tree & Vitex negundo & whole plant \\
\hline 07 & Gunja & Rosary pea & Abrus precatorius & seeds \\
\hline 08 & Neeli & True indigo & Indigofera tinctoria & whole plant \\
\hline 09 & Bhringraj & False daisy & Eclipta prostrate & whole plant \\
\hline 10 & Saireyaka & Porcupine flower & Barleria prionitis & leaf \& Root \\
\hline 11 & Japa & China rose & Hibiscus rosa - sinensis & flower \\
\hline 12 & Bijaka & Indian kino tree & Pterocarpus marsupium & stem core \\
\hline 13 & Tila & Sesame & Sesamum indicum & seed \\
\hline
\end{tabular}

Kashisham Bhasma, Saptamrita Lauha and Narsingh Rasayan also have Keshya properties. Rasayan contains various phytochemicals and vitamins which are favourable for hairs.
This is explained with the broad heading of Keshya concept. So the goodness of hair can be understood by three perspectives like-

- Kesha sanjanana: that which helps in the origin of hair. 
- Kehsha vardhana: that which promotes hair growth or which makes hair dense and thick.

- Kesha ranjana: that which gives dark black color to the hair.

\section{Diseases of hairs in ayurvedic classics}

\section{(a) Khalitya}

Khalitya is one of the Kșudra Roga [18]. Vata, Pitta, Kapha and Rakta are involved in Khalitya as mentioned in the texts [18].

According to Ayurveda, the vitiated Vayu and Pitta having recourse to the root of the hairs make the hairs falls off, while the vitiated blood and Kapha of the locality fill up the hair follicles, thus blocking their fresh growth.

There is redness of scalp in diseased region which indicates towards involvement of Pitta. A case study on Ayurvedic management of Khalitya (Alopecia areata) by Virechana Karma(Purgation)and concurrent use of systemic medicines and Rasayan drugs shows that Virechana karma is extremely beneficial in the management of Khalitya (Alopecia areata) [19]

\section{Treatment of Khalitya}

1. The affected part should be scraped by Karkash Patra (leaves for scraping) such as Mallotus philippinensis and should be applied the following Lepa (paste) or oil preparation.

(a) Lepa of Gunja (Abrus precatorius) seed powder[20]

(b) Hasti-Dantamashi (elephant task) lepa [21]

(c) Hasti-Dantamashi(elephant task) -Rasanjan lepa[21]

(d) Bhalatakadi (Semicarpus Anacardium) lepa[21]

(e) Madhukadi lepa. In this Lepa Yasthimadhu (Glycyrrhiza glabra), lotus, Manuka (Vitis vinifera), oil, ghee and milk in equal amount should be applied [22].

(f) Oil preparation by Malati (Myristica fragrans), Karavira (Nerium indicum), Chitraka (Plumbago zeylanica) and Karanja (Pongamia pinnata)[20].

(g) Hasti-danta (elephant task) along with Til taila (Sesamum indicum oil)[21].

(h) Lepa of Gokshur (Tribulus terrestris), Til (Sesamum indicum), honey and ghee should be applied on the scalp [22].

(i) Swaras (juice) of Patol (Trichosanthes dioica) leaves applied for 3 days said to cure Khalitya[22].

(j) Snuhidugdha taila[22](Euphorbia nerifolia)

2. Rasayana medicine (rejuvenation therapy) should be administered [20] as it is difficult to cure and as such cannot be eliminated without Rasayana.

3. Acharya Charaka has mentioned Khalitya in Chikitshasthan $26^{\text {th }}$ chapter and stated that first Vaman (emesis) and Virechan (purgation) therapy should be given, then Nasya (Administration of drugs by the route of nasal cavity) treatment and then oil for massaging hair and scalp, should be given to the patient. He mentioned Vidarigandha taila (Desmodium gangeticum) and Tiladi yoga for local application [23].

4. Chameli (Jasminum officinale), Karanja (Pongamia pinnata) and Varun (Crataeva nurvala) paste should be used for Abhyanga[22].

5. Rakta-mokshana (Bloodletting - Removal of impure blood) is also a best therapy in Khalitya[20].

About one lakhs hairs are present in Scalp. Around one hundred hairs are lost daily in normal person. If the number increases manifold. This disease is called Alopecia. There are of 2 types- (i) Noncicatricial alopecia (ii) Cicatricial alopecia, which is further of different type, on the basis of location, pattern and cause [24].

Topical minoxidil, Antiandrogens like finestride, cyproterone, spionlactone, flutamide, cimetidine and Hair transplant surgery are use in modern medicine.

\section{(b) Palitya}

The Agni and Pitta of the body having recourse to the head owing to overwork and fatigue tend to make the hair prematurely grey. Palitya disease has been explained in all Samhitas in different chapter. Sushrutha explains Palithya in Kshudra Rogaadhikara[25], Vagbhatta in Shiro Kapalagata Roga[26] and Charaka under Urdhwa jatrugata $\operatorname{Rog} a[27]$.

On the basis of different Doshas these Lakshana is found in the Palitya: Hairs are split, ash colour, rough, dry and resembles water- Vataja, Burning sensation in the scalp and the hairs are yellowish. -Pittaj, The scalp is unctuous and hairs are growing thick and white. -Kaphaja, Presence of all the features should be noticed. -Tridoshaja[28].

\section{Treatment of Palitya}

1. In Ayurveda, Nasya treatment is stated as one of the best treatment for Palitya. Different oils are described in different Ayurvedic text for Nasya therapy in Palitya.

(a) Vidarigandha taila (Desmodium gangeticum)[29]

(b) Sahacharadi taila (Barleria prionitis L.)[29]

(c) Bhringaraj taila (Eclipta alba) [30]

(d) Prapondaraki taila (Nymphaea lotus)[29]

(e) Nimba taila(Azadirachta indica)[ [30]

(f) Sheilu taila(Cordia wallichii G.DON)[ [30]

(g) Maha nila taila (Indigofera tinctoria) [29]

2. Different Yoga (formulation) are also mentioned for Lepa [29]

(a) Dugdhika-karavira yoga

(b) Tiladi yoga

3. Loha yoga decoction has been suggested for washing hair[31]. 
4. Triphala, Nilivruksha, Loha Bhasma, Bhringaraja mixed with sheep's urine should be applied, which makes the hair black [31].

Premature greying is an important cause of low self-esteem, often interfering with socio-cultural adjustment. And it is a burning problem as large percentage of population especially young men and women in present times are suffering. In Ayurveda premature graying of hair is called as Akala Palitya. The incidence of premature ageing along with Akala Palitya is on increase, particularly in tropical and developing countries. According to W.H.O in India, its incidence is high in the age group of 20-30 years. Hence premature graying has long attracted researchers and industry alike with scientific as well as commercial targets. Hair coloring involves the use of chemicals which can result in a range of adverse effects like allergic reaction.

\section{(c) Indralupta}

'Indralupta' or 'Alopecia areata' is mainly a cosmetic condition where we find a patchy loss of previously existing body hairs. When we go through different Ayurvedic texts lot of references are found indicating the use of poisonous drugs as an external application for various types of diseases \& alopecia areata is a disease which requires a topical type of treatment. It is one of the common therapeutic problems which challenge the skill of the people working in the field of dermatology.

Alopecia areata is also known as spot baldness. It is a common autoimmune skin disease causing hair loss on the scalp, face and sometimes on other areas of the body. Alopecia can be the cause of psychological stress; individuals with it may experience social phobia, anxiety and depression.

In modern medicine topical or injected corticosteroids are used to treat this condition. Alopecia areata is the commonest cause of patchy hair loss. It may be regarded as an immune-mediated type of hair loss. The condition affects $0.1 \%$ to $0.2 \%$ of the population and occurs in both males and females. A single round or oval patch of complete baldness develops rapidly usually over the vertex or in the occipital region. There are no subjective symptoms and the denuded area of scalp is of normal color and texture. Patches in the beard may occur alone or in association.

\section{(d)Darunaka}

Different Ayurvedic classics describe hair disease like Darunaka in which due to kapha pita prakopa the scalp becomes hard itchy rough and scaly. In Darunaka the dead tissue shedding down from scalp, with symptoms like Kandu, Kesha Chyuti Rookshata, Twaksputana, etc. due to the vitiation of Vata and Kaphadosha. It affects almost everyone atleast sometime during their adult life and cause significant discomfort.

\section{Treatment of Darunaka}

1. Snehan (anointment) and Swedan (fomentation) are the best remedies for Darunak [20].

2. Sira veda (taking out of impure blood), Avapida nasya therapy and Sirobasti are very effective [20].

3. Abhyanga (massage) with oil which will decrease the vitiation of Vata and Kapha like oil prepared from Gunja (Abrus precatorious) and Bhringaraj (Eclipta prostrata) should be used [20].

4. The affected parts should be washed with the alkaline solution of Kodrava weeds [20].

5. For local application - paste of Chironji seeds (Buchanania lanzan), Yashtimadhu root (Glycyrrhiza glabra), Kutha stem (Saussurea lappa), Urad seed (Vigna mungo) and Saindhav lavan mixed with honey or application of paste of seed of mango powder with Haritaki (Terminalia chebula) powder is also suggested[20].

6. Tankan (Borax) is applied on hair and kept for 5 to 10 minutes and then washed out [32].

Dandruff (Pityriasis Capitis) is a common scalp disorder, characterized by presence of corneocytes that form clusters due to their high cohesive power, in the form of flaky white to yellowish scales, accompanied by itching. It has been observed that affecting almost half of the population at the prepubertal age and of any gender and ethnicity [33]. It occurs in both sexes and persons of all races [34]. The peak incidence and severity of dandruff occurs at approximately 20 years of age [35]. It is considered as very frequent, and appears to be more frequent among men than women and more frequent among young people than older people. No population in any geographical region would have passed through freely without being affected by dandruff at some stages in their life. Dandruff affects aesthetic value and often causes itching.

It has been well established that keratinocytes play a key role in the expression and generation of immunological reactions during dandruff formation. The severity of dandruff may fluctuate with season as it often worsens in winter [36].A study done by [37] showed that clinically Siro-abhyanga [38] procedure with Gunjataila [39], with Nimbatwak churna showed better results in treating Darunak.

\section{CONCLUSION}

Hair is an important part of our body. It not only enhance the beauty but also serve as body guard of skull during mild injury by reducing the impact of force by providing cushion like features. Disease of hair is early signal of some systemic and chronic disease. Nutrition of Dhattu promotes the Upadhatu and Mala. So nourishment of Asthi Dhatu and Treatment of Asthi Dhatu Vikar is essential required for the treatment of the hair disease. Multiple nutrient deficiencies may 
result in hair loss. Nutrient deficiencies may arise due to genetic disorders, medical conditions, or dietary practices. As far as the matter of hair and its growth is concerned, once again we can deduce the need of nutrition and essential body requirements as it is formed/derived from the subsequent tissues. So providing the nutrition to the previous Dhattu and along with concern Dhattu is the necessary to provide the nutrition for Updhattu and Mala. In Ayurvedic classics so many Yogas (Formulation) and Chikitsa Karama (Treatment methods) are described in texts. Many OTC Hair Care products are in market are not showing significant result due to improver use.

\section{AKNOWLEDGMENT}

I am very thankful to, Dr. Sushma Rawat \& Dr. Suchi Mitra of Rasa Shastra \& Bhaishajya Kalpana Department for providing valuable suggestion and helping in preparation of this manuscript.

\section{REFERENCES}

1. Engler, R. J., \& Li, X. M. (2014). Complementary and Alternative Medicine. In Middleton's Allergy (pp. 1636-1661). Content Repository Only!.

2. Shastri, K., \& Chaturvedi, G. N. (2009). Vidyotini Hindi Commentary on Charak Samhita, Part 1, Sutra Sthana, Chapter 10 verse 7.

3. Atridev, G.K.(2007). Vidyotini Hindi commentary on Astangahridya of Vagbhata, Sutrasthan, chaukhamba prakashan, Varanasi, reprint edition. verse- 2/19: 27.

4. Atridev, G. K.(2007). Vidyotini Hindi commentary on Astangahridya of Vagbhata, Sutra Sthana, chaukhamba prakashan, Varanasi, reprint edition, verse-2/48, 32.

5. Shastri, K.(2008). Vidyotini Hindi commentary on Charaka Samhita Part 1, Sutra Sthana, Chaukhamba Sanskrit Sansthana, Varanasi, edition 8, verse- 6/4, 92 .

6. Shastri, K.(2008). Vidyotini Hindi commentary on Charaka Samhita Part 2, Chikitsa Sthana, Chaukhamba Sanskrit Sansthana ,Varanasi, edition 8 , verse- $1 / 1 / 7-8$, pp- 3 .

7. Candrashekran, T. (1952). Anadkanda, Madaras Government oriental series, Edition verse-23/10, 384.

8. Sharma, M. G. (2014). Hindi commentary on Ayurved Prakash, edition, verse- 3/2, 343.

9. Shastri, A. (2010). Rasa ratana sammuchaya, Chaukhamba Amar Bharti Prakashan, Varanasi edition 10 verse- 4/1, 90 .

10. Shastri, K. (2009). Hindi commentary on Rasa Tarangini of Sadanand Sharma, $11^{\text {th }}$ edition, Motilal Banarsi das, verse- 24/7-8, 343.

11. Billero, V., \& Miteva, M. (2018). Clin Cosmet Investig Dermatol, 149-159.

12. Al-Aradi, I., \& Al-Ghareeb, M. Hair Fall: Common Causes and Treatment Modalities.
13. JS Pasricha, G.R. (2001). Illustrated Textbook of Dermatology, $2^{\text {nd }}$ edition 2001, New Delhi; Jaypee Brothers; 118.

14. https://www.scribd.com/collections/3567269/ Halayudha-Kosha (Jaishankar Joshi, Halayudha Kosh) edition $2^{\text {nd }}, 245$.

15. Shastri, K., \& Chaturvedi, G. N. (2009). Vidyotini Hindi Commentary on Charak Samhita, Part 1, Sutra Sthana, Chapter 10 verse 7.

16. Shastri, A. (2017). Hindi commentary on Sushruta Samhitha Part 1, Sharira sthana, Chaukamba surbharati prakashan,Varanasi reprint, verse- 9/9, pp- 94 ..

17. Verma, S., \& Yadav, J., Sharir, K.V. (2009). Chaukambha Orientalia, Varanasi, $1^{\text {st }}$ Edition, 214.

18. Shastri, A. (2017). Hindi commentary on Sushruta Samhitha Part 1, Nidana sthana, Chaukamba surbharati prakashan,Varanasi reprint, verse13/34, 322.

19. Rahul, S., Bedarkar, P. B., Varsakiya, J., \& Prajapati, P. (2017). Alopecia Areata (Indralupta): A case successfully treated with Ayurvedic Management. Journal of Ayurvedic and Herbal Medicine, 3(3), 111-115.

20. Sharma, P.V. (2013). English translation of text and Dalhana's commentary along with critical notes on Sushrut Samhita vol 2, Chaukhamba Visvabharati prakashan, Varanasi, edition. 463464.

21. Sen, K. G. D., \& Ratnavali, B. (2007). Edited with 'Siddhiprada'Hindi commentary by Prof. Siddhi Nandan Mishra, Chaukhamba Surbharati Prakashan, 1196.

22. Mishra, B. S. (2015). Vidyotini Hindi commentary on Bhav Prakash of Bhavamisra, 2, Chaukhamba Sanskrit Sansthan Varanasi, 586.

23. Bhagwan Dash, R.K. (2014). Sharma, text with English translation \& critical exposition based on Cakrapani datta's Ayurveda Dipika, Charak Samhita, , Chaukhamba Sanskrit Sansthan Varanasi, edition. 540.

24. Khanna, N. (2009). Illustrated synopsis of Dermatology and sexually Transmitted Diseases 3rd edition 2009, Reed Elsevier India Private Limited, Delhi, India, 110-118.

25. Shastri, A.(2017). Hindi commentary on Sushruta Samhitha Part 1, Nidana sthana, Chaukamba surbharati prakashan, Varanasi reprint, verse13/36, 369.

26. Atridev G.K.(2007). Vidyotini Hindi commentary on Astangahridya of Vagbhata, Uttara Sthana, chaukhamba prakashan, Varanasi, reprint edition, verse-23/29, 535.

27. Shastri, K.(2008). Vidyotini Hindi commentary on Charaka Samhita Part 2, Chikitsa Sthana, Chaukhamba Sanskrit Sansthana ,Varanasi, edition 8, verse- 26/262, pp- 676 . 
28. Murthy, K.R. (2000). Srikanta, Hindi commentary on Astangahridya of Vagbhata, Krishnadas Academy, Varanasi, Edition $3^{\text {rd }}$, AD. 586.

29. Bhagwan, Dash R.K. (2014). Sharma, Charak Samhita (text with English translation \& critical exposition based on Cakrapani datta's Ayurveda Dipika). Chaukhamba Sanskrit Series office Varanasi, edition. 541-543.

30. Mishra, S.N. (2015). Hindi commentary on Bhaisajya Ratnavali of Kaviraj Govind Das Sen edited with 'Siddhiprada' Chaukhamba Surbharati Prakashan Varanasi, edition. 939-940/937.

31. Misra, B.(2015). Vidyotini Hindi commentary on Bhav Prakash of Sri Bhamisra vol 2; Chaukhamba Sanskrit Bhawan, Varanasi, edition, 587.

32. Shaikh, S.M. (2016). A Review on: Physicochemical evaluation of ayurvedic mineral drug Tankan Bhasma, 4, 23-27.

33. Elewski, B.E. (2005). Clinical diagnosis of common scalp disorders. J Investig Dermatol Symp Proc, 10:190-3
34. Giacomoni P. U., Mammone T., \& Teri, M. (2009). Gender-linked differences in human skin. J Dermatol Sci. 55, 144-149.

35. Leyden, J.J., \& Kligman, A.M. (1979). (Dandruff: Cause and Treatment), Cosmetics \& Toiletries, 94, 23(24).

36. Piérard-Franchimont, C., Xhauflaire-Uhoda, E., Piérard, G.E. (2006). Revisiting dandruff. Int J Cosmet Sci. 28:311-8.

37. Venkata, D., Krishna, N., Srikanth, P.B. (2016). 'Study on efficacy of Gunja Taila Shiro abhyanga and Nimba twak churna in the management of Darunaka W.S.R Pityriasis Capititis' IJAPR, 4; 15-20.

38. Bhagwan, Dash, R.K. Sharma Charaka Suthrastanam Vol I, Chaukhamba Sanskrit Sansthana, Varanasi, edition 8, verse-5/83, 124.

39. Nisteshwar, K. Text book of Dravyaguna, chaukambha surabharati prakashan, 419. 